\title{
Genetic and epigenetic alterations of steroidogenic factor-1 in ovarian tumors
}

\author{
SARAH MILLER $^{1}$, NOBEL BHASIN ${ }^{2}$, HEATHER URREGO ${ }^{3}$, KRZYSZTOF MOROZ ${ }^{3}$, \\ BRIAN G. ROWAN ${ }^{4}$, MEERA S. RAMAYYA ${ }^{5}$ and NICK M. MAKRIDAKIS ${ }^{2}$
}

\author{
${ }^{1}$ The Ohio Department of Health, Columbus, OH 43215; ${ }^{2}$ Department of Epidemiology and Tulane Cancer Center, \\ Tulane University; Departments of ${ }^{3}$ Pathology and ${ }^{4}$ Structural and Cellular Biology and Tulane Cancer Center, \\ Tulane University School of Medicine, New Orleans, LA 70112; ${ }^{5}$ Department of Pediatrics, John A. Burns \\ School of Medicine, University of Hawaii, Honolulu, HI 96813, USA
}

Received October 4, 2012; Accepted November 12, 2012

DOI: $10.3892 /$ ijo.2012.1758

\begin{abstract}
Steroidogenic factor-1 (SF-1), the product of the NR5A1 gene, is an essential transcription factor that is known to regulate steroidogenesis in ovarian epithelia, including the synthesis of progesterone, a suppressor of ovarian cancer. Expression of the SF-1 protein, a potential ovarian tumor suppressor, has been demonstrated in normal OSE cells, but is lost in most ovarian tumors and ovarian tumor cell lines. We examined loss of heterozygosity $(\mathrm{LOH})$ and promoter methylation as potential mechanisms that may explain the loss of SF-1 protein in ovarian tumor tissues. Genotyping of three NR5A1 SNPs in matched tumor/normal tissues identified $\mathrm{LOH}$ in 16/36 (44\%) of the ovarian tumors successfully analyzed, and somatic mutations (gain of allele) in $10 \%$ of the tumors. Furthermore, a methylation-sensitive restriction enzyme method was used to demonstrate statistically significant $(\mathrm{p}<0.0001)$ increase in the frequency of NR5A1 gene methylation in ovarian tumors $(36 / 46 ; 78 \%)$ versus normal ovaries $(1 / 11 ; 9 \%)$. These data suggest that the SF-1 encoding gene exhibits frequent genetic ( $\mathrm{LOH} /$ base substitution) and epigenetic (methylation) somatic alterations in ovarian tumors. These data also present novel molecular mechanisms that may explain the loss of SF-1 protein in ovarian tumors, and its potential role in ovarian carcinogenesis.
\end{abstract}

Correspondence to: Professor Nick Makridakis, Department of Epidemiology and Tulane Cancer Center, Tulane University, New Orleans, LA 70112, USA

E-mail:nmakrida@tulane.edu

Abbreviations: SF-1, steroidogenic factor-1; StAR, steroidogenic acute regulatory protein; OSE, ovarian surface epithelial; ER $\alpha$, estrogen receptor $\alpha$; ER $\beta$, estrogen receptor $\beta$; EOC, epithelial ovarian cancer; Rb1, retinoblastoma 1; SNP, single nucleotide polymorphism

Keywords: somatic, mutation, ovarian, carcinogenesis, steroidogenesis

\section{Introduction}

Ovarian cancer is the most frequent cause of death from gynecologic neoplasm in the Western World, mainly due to lack of early detection and understanding of its etiology (1). Most ovarian malignancies have epithelial origin and are often derived from ovarian surface epithelial (OSE) cells (2). Thus, understanding the molecular mechanisms that control OSE cell proliferation and differentiation may lead to the design of novel targeted therapies. Normal human OSE cells are capable of steroidogenesis (3-5) and in epithelial ovarian cancer (EOC), intratumoral steroid biosynthesis is closely linked with carcinogenesis $(2,5,6)$.

Several studies support a role for SF-1 as a suppressor of ovarian cancer: i) ectopic expression of SF-1 inhibits rat ovarian epithelial cell proliferation, causing cell cycle arrest and promoting apoptosis (7); ii) the tumor suppressor Rb1 synergizes with steroid receptor co-activator-2 (SRC-2) to enhance the activity of SF-1 as well as nuclear receptors ER $\alpha$ and $\operatorname{ER} \beta$ (8); Rb1 may thus promote the transcription of target genes linked to cell differentiation; iii) SF-1 promotes differentiation of human and rat granulosa cells associated with the developing oocytes (9).

It is well established that OSE cell proliferation and ovarian steroidogenesis are closely linked $(2,5,6)$. Specifically, both cell culture and epidemiologic data support a protective role for progesterone against ovarian cancer $(10,11)$. In addition to upregulating steroidogenic enzymes p450scc and 3 $\beta$-HSD II, SF 1 stimulates expression of the human StAR gene (12). The expression and functional integrity of the StAR protein and enzymes p450scc and 3 $\beta$-HSD II are particularly important for progesterone biosynthesis (13).

We have previously shown that while human SF-1 and StAR are expressed in normal OSE cells, ovarian cancer cell lines SKOV-3, OVCar3 and BG1 do not show SF-1 or StAR expression (14). We then utilized immunohistochemistry to demonstrate that the vast majority of the human ovarian tumor tissues examined do not express SF-1 protein (unpublished data). In addition, real-time PCR studies on epithelial ovarian cancers suggest that StAR mediated progesterone biosynthesis may inhibit OSE tumor cell proliferation (15). Collectively these 
studies support the hypothesis that loss of SF-1 protein may contribute to carcinogenesis in ovarian epithelial cells, in part, through decreased progesterone biosynthesis.

It is noteworthy that the human NR5Al gene has been mapped to chromosome 9 at position 9q33 (16), a region that shows genetic alterations ( $\mathrm{LOH}$, microsatellite instability, and amplification) in more than half of ovarian tumors (17). Particularly significant is the observation that nearly all of the tumors that show genetic alterations at $9 q$ include the subchromosomal region 9q32-34, suggesting that a candidate tumor suppressor gene may reside in this region (17). The location of human SF-1 in the region of 9q33 supports our hypothesis that SF-1 is a candidate tumor suppressor gene in the ovary and that abolished or aberrant SF-1 expression in OSE cells may promote tumor growth. We thus decided to examine the degree of $\mathrm{LOH}$ in ovarian tumors, specifically at the NR5A1 locus and report $\mathrm{LOH}$ in $44 \%$ of the tumors.

Methylation controls the time and cell-type specific NR5A1 gene expression in the endocrine system (18). Thus we examined the methylation status of the NR5A1 gene promoter in ovarian tumors, and report significantly higher prevalence of NR5A1 gene methylation in ovarian tumors compared to normal (i.e. non-tumor) ovaries. These data suggest that LOH and methylation may contribute to the loss of SF-1 protein in ovarian tumors, which in turn may result in ovarian carcinogenesis.

\section{Materials and methods}

Samples. Following approval of a research protocol by the Institutional Review Board Committees of Tulane University and Louisiana State University in New Orleans, 66 archival formalin-fixed paraffin-embedded (FFPE) tissue blocks of ovarian tissue were obtained from the Departments of Pathology at the Tulane University Health Sciences Center and from the Interim LSU Hospital. Sixteen samples were representative of normal ovaries from women who had undergone gynecological surgeries for non-ovarian related causes. The rest of the 50 samples consisted of 3 benign ovarian tumors, 7 tumors of low malignancy potential and 40 cases of ovarian carcinoma. Each case of ovarian tumor was matched with corresponding benign tissue control. All FFPE tissue blocks were sectioned and stained with hematoxylin and eosin for histological assessment.

\section{DNA extraction}

FFPE tissue blocks. Tissue (1.5-2 mg) was excised from each normal and tumor FFPE tissue block using a sterile scalpel and placed in an autoclaved $1.5 \mathrm{ml}$ centrifuge tube. Samples were deparafinized with $1 \mathrm{ml}$ of xylene followed by vortexing at top speed for $2 \mathrm{~min}$. The tissue was then centrifuged at $10,000 \times \mathrm{g}$ for 3 min using Microcentrifuge 16 from Beckman Coulter Inc. (Brea, CA, USA) and the supernatant was pipetted out. To remove any residual xylene and facilitate pelleting, $1 \mathrm{ml} \mathrm{100 \%} \mathrm{ethanol} \mathrm{was} \mathrm{added} \mathrm{to} \mathrm{the} \mathrm{tissue} \mathrm{sample,} \mathrm{followed}$ by spinning at $10,000 \mathrm{x}$. The supernatant was decanted and tissue pellets were allowed to air-dry at room temperature. Subsequently, pellets were subjected to protease digestion by $100 \mu \mathrm{l} / \mathrm{ml}$ proteinase $\mathrm{K}$ in Digestion Buffer [10 mM Tris- $\mathrm{HCl}$ (pH 8.0), $1 \mathrm{mM}$ ethylenediaminetetraacetic acid (EDTA)] at $52^{\circ} \mathrm{C}$ for $16 \mathrm{~h}$. Following the digestion, DNA was isolated using the Qiagen (Valencia, CA, USA) DNeasy for FFPE kit, following the manufacturer's recommended protocol.

Normal ovarian tissue samples. Ovarian surface epithelial cells from normal ovarian FFPE tissue samples were dissected using the PALM ${ }^{\circledR}$ Robot Microbeam laser microdissection system (PALM GmbH, Bernried, Germany) at the Louisiana State University Morphology and Imaging core facility. DNA was then extracted from the epithelial cells using the proteinase $\mathrm{K}$ DNA extraction Solution and incubation at $65^{\circ} \mathrm{C}$ for $16 \mathrm{~h}$, as suggested by the manufacturer (Arcturus ${ }^{\circledR}$, Applied Biosystems, Life Technologies Corporation, Carlsbad, CA, USA).

Genotyping. Both tumor and normal DNA samples were genotyped for SNPs: rs2279605, rs10120967, rs7851737 using Applied Biosystems TaqMan probes, with IQ power mix (Bio-Rad, Hercules, CA, USA) or Amplitaq Gold, $25 \mathrm{mM}$ $\mathrm{MgCl}_{2}$ and 10X PCR Gold buffer from Applied Biosystems and dNTPs from VWR International (Radnor, PA, USA). Applied Biosystems Taq Man probes are labeled with Fam and Vic dyes. A total of $20 \mu \mathrm{l}$ PCR reactions were set up in a 96-well plate which was covered with Microseal 'B' film from Bio-Rad. Bio-Rad Thermal cycler IQ5 was used to run the real-time PCR and Image Quant 5 software from Bio-Rad used for plate read document and analysis of the real-time data post PCR. All genotyping assays were done in triplicates and when the three independent assays yielded ambiguous results, were repeated again.

Digestion of genomic DNA for methylation study. DNA $(0.5 \mu \mathrm{g})$ from each sample (tumor and normal from the same patient) was digested using 5 units of Afel enzyme (New England Bioscience, Ipswich, MA, USA) in a total reaction volume of $50 \mu \mathrm{l}$. The digestion was performed in 1X NEBuffer (New England Bioscience); 1X NE buffer contains: $20 \mathrm{mM}$ Tris-acetate, $50 \mathrm{mM}$ potassium acetate, $10 \mathrm{mM}$ magnesium acetate, $1 \mathrm{mM}$ dithiothreitol ( $\mathrm{pH} 7.9$ at $25^{\circ} \mathrm{C}$ ). The samples were incubated with the enzyme for $1 \mathrm{~h}$ at $37^{\circ} \mathrm{C}$ to allow digestion of DNA, following which Afel was inactivated by incubating the samples at $65^{\circ} \mathrm{C}$ for $20 \mathrm{~min}$. Alternatively, digestion was performed overnight.

PCR amplification for methylation study. All samples were simultaneously PCR-amplified for the promoter region of the $\beta$-actin gene and NR5Al gene in $200 \mu \mathrm{l}$ tubes. For each $50 \mu \mathrm{l}$ reaction, $2 \mu \mathrm{l}$ of DNA was used and reagent concentrations were optimized at: $5 \mathrm{mM}$ for $\mathrm{MgCl}_{2}$ from Applied Biosystems, $2 \mathrm{mM}$ for each dNTP from VWR; $5 \mathrm{mM}$ for primers $(\beta$-actin, forward primer: 5'-TGC AAA GAA CAC GGC TAA GTG TGC-3', $\beta$-actin, reverse primer: 5'TCT AAG ACA GTG TTG TGG GTG TAG GT-3', NR5A1 gene, forward primer: 5'-AAC ACC AAC AAA GAA GGC GAG AGG-3', NR5Al gene, reverse primer: 5'-TCA CTT ACG AAG CGG AAG CAGC-3') from IDT DNA (Coralville, IA, USA) in 10X PCR buffer II [final concentration: $50 \mathrm{mM}$ potassium chloride and $10 \mathrm{mM}$ Tris- $\mathrm{HCl}$ ( $\mathrm{pH} 8.3$ at room temperature) from Applied Biosystems] along with 1.25 units AmpliTaq ${ }^{\circledR}$ DNA polymerase per $50 \mu \mathrm{l}$ of reaction. PCR amplification was performed on a PTC-100 ${ }^{\mathrm{TM}}$ programmable thermocycler from MJ Research Inc. (Quebec, Canada) allowing initial denaturation at $95^{\circ} \mathrm{C}$ for $20 \mathrm{~min}$ followed by 40 cycles of $95^{\circ} \mathrm{C}$ for $1 \mathrm{~min}, 62^{\circ} \mathrm{C}$ for 
$1 \mathrm{~min}, 72^{\circ} \mathrm{C}$ for $1 \mathrm{~min}$ and completing the terminal extension with $10 \mathrm{~min}$ at $72^{\circ} \mathrm{C}$.

Gel electrophoresis. A total of $8 \mu \mathrm{l}$ of PCR product was added to $2 \mu \mathrm{l}$ of loading dye ( $2 \%$ xylene cyanol, $40 \%$ glycerol in $\mathrm{DDi}_{2} \mathrm{O}$ ) from Boston Bioproducts (Ashland, MA, USA). For sizing $1 \mathrm{~kb}$ plus DNA ladder (Invitrogen, Life Technologies Corporation, Carlsbad, CA, USA) was loaded on a $2 \%$ agarose gel containing $1 \mathrm{X}$ Tris-acetate-EDTA buffer $(40 \mathrm{mM}$ Tris acetate and $1 \mathrm{mM}$ EDTA) and $5 \mu \mathrm{g}$ of ethidium bromide for staining. The gel was run on a horizontal system for Gel electrophoresis from Bethesda Research Laboratories Inc. (Gaithersburg, MD, USA) at $100 \mathrm{~V}$ for $60 \mathrm{~min}$. Following the gel electrophoresis the amplified fragments were visualized on Molecular Imager ${ }^{\circledR} \mathrm{Gel}$ Doc $^{\mathrm{TM}}$ using Image $\mathrm{Lab}^{\mathrm{TM}}$ software from Bio-Rad.

Methylation analysis. Electrophoretic images were analyzed for relative (NR5A1/ $\beta$-actin) band intensity using Image Quant 5.1 software from GE Healthcare (Piscataway, NJ, USA). Relative intensities were categorized in quartiles as follows: -, 1st; + 2nd; $++3 \mathrm{rd} ;+++4$ th quartile. All experiments were done at least twice and the relative intensities were averaged.

Clinical application. A retrospective chart review was performed gathering clinical data on the patients for whom we had malignant ovarian tissue. Characteristics examined were: age, race/ethnicity, date of diagnosis, years survived since diagnosis, stage of ovarian cancer, histologic grade, date of debulking surgery and treatment with chemotherapy or radiation.

Statistics. For most statistical calculations, two-tailed p-values were obtained using Fisher's exact test. The log-rank test was used for calculating $\mathrm{p}$-values for potential differences in survival.

\section{Results}

Samples. The clinical characteristics of the ovarian tumor samples examined are shown on Table I.

LOH at the NR5A1 locus in ovarian tumors. In the current study, we considered two molecular hypotheses of SF-1 protein loss in ovarian tumors: $\mathrm{LOH}$ and increased methylation. To probe for the prevalence of $\mathrm{LOH}$ at the NR5Al locus, we genotyped matched ovarian tumor and normal FFPE tissue DNA samples from the same ovarian cancer patient, for three NR5AI gene SNPs: rs2279605, rs10120967 and rs7851737. SNPs were selected based on the following criteria: i) high ( $>30 \%)$ frequency of heterozygosity in the racial/ethnic groups present in our study population (based on available data at dbSNP: http://www.ncbi.nlm.nih.gov/projects/SNP/); ii) availability of a preoptimized Taqman SNP Genotyping Assay for each SNP. Genotyping was performed by Taqman SNPGenotyping Assays using real-time PCR. Assays were performed in triplicates and repeated again, if the genotyping results were ambiguous. All three genotyped SNPs were in Hardy-Weinberg equilibrium in normal samples (data not shown).

The genotyping results for the ovarian tumors and the $\mathrm{LOH}$ data for each sample, are shown in Fig. 1A. These data show that out of the 36 ovarian tumor tissues that were heterozygous for at least one of the three NR5Al gene SNPs, $16(44 \%)$ had LOH
(Figs. 1A and 2). The majority of the ovarian tumors had a single $\mathrm{LOH}$ event at the NR5Al locus (out of maximum three possible), but 5 tumors (14\%) showed multiple LOH events (Fig. 1A). Also, each SNP showed LOH in multiple tumors, with rs7851737 showing most losses (Fig. 1B). Thus, LOH occurs frequently at the NR5Al locus in ovarian tumors.

With regards to the type of observed loss, $\mathrm{LOH}$ events at rs2297605 were equally distributed between the two alleles, while the other two SNPs showed bias in the LOH events towards one of the two alleles (Fig. 1B). The significance of this finding is unclear, since these are non-coding SNPs. Interestingly, the genotyping results (Fig. 1A) also uncovered somatic mutations other than $\mathrm{LOH}$ in the tumors, manifested as allele gains; base substitutions turning a homozygous genotype (normal DNA) into a heterozygote genotype in the tumor, hence called 'gain of allele'; Fig. 1B. These somatic NR5Al substitutions were present in $10 \%$ of ovarian tumors (Fig. 2). Thus the genotyping data show frequent genetic ( $\mathrm{LOH} /$ substitution) events at the NR5AI locus in ovarian tumors.

Methylation of the NR5Al gene in ovarian tumors. A methylation-sensitive restriction enzyme (Afe1) method (e.g. 19) was used to quantify site-specific methylation at $-30 \mathrm{bp}$ (compared to translation start) of the $N R 5 A 1$ gene promoter in ovarian tumor tissue from patients with ovarian cancer and in matched normal tissue from the same patients (when available).

Afe1 cleaves genomic DNA at 5'-AGC/GCT-3', but cleavage is blocked by methylation (http://www.neb.com/nebecomm/ products/productr0652.asp). Since the Afel enzyme cleaves the un-methylated $\mathrm{CpG}$ 's, only methylated $\mathrm{CpG}^{\prime}$ s can be amplified and quantified following gel electrophoresis. Complete DNA digestion was confirmed by prolonged (overnight) Afe1 digestion, which yielded similar results (data not shown). To control for differences in DNA level and/or quality between tumor samples, we also amplified $\beta$-actin as an internal control. The primers used for the $\beta$-actin gene were selected to amplify a region that lacks an Afe1 cleavage site. Therefore, $\beta$-actin is amplified regardless of methylation status, and relative band intensity (NR5A1/ $\beta$-actin) was used as a function of NR5Al gene methylation (see Materials and methods for details). This analysis indicated that 36 out of $46(78 \%)$ ovarian tumors had appreciable NR5A1 methylation (2nd, 3rd and 4th quartile of methylation levels), and 17/46 (37\%) had high levels of NR5A1 methylation (3rd and 4th quartile of methylation levels; Table II). Thus the NR5A1 gene is methylated in most ovarian tumors. Furthermore, we detected both a high level of NR5AI gene methylation and $\mathrm{LOH}$ in $21 \%$ of the ovarian tumors that we analyzed (Fig. 1 and Table II). The cumulative data also demonstrate that $62 \%$ of the ovarian tumors have $\mathrm{LOH}$, high level of methylation, or both (Fig. 2) at the NR5Al locus.

As indicated by Table I, most ovarian tumors are diagnosed at an advanced stage, reducing the ability to obtain normal ovarian tissue from most patients. In the absence of an adequate number of matched normal ovaries available for study, 16 non-tumor ovaries were analyzed (from unrelated individuals) to evaluate the relative methylation of the promoter region of the NR5Al gene in normal ovarian tissue, with the same methylation-sensitive restriction enzyme method used above. Since human ovarian tumors have epithelial origin $(2,20)$, we obtained OSE cells from these ovarian tissues (by 


\begin{tabular}{|c|c|c|c|}
\hline Sample & rs10120967 & rs7851737 & rs2297605 \\
\hline 1 & $A A$ & GG & $A A$ \\
\hline 2 & AA & GG & AA \\
\hline 3 & AG & $A A$ & GG \\
\hline 4 & $A A$ & $A A$ & $A A$ \\
\hline 8 & $A A$ & AA & $\mathrm{AG}$ \\
\hline 9 & $A A$ & GG & $\mathrm{AG}$ \\
\hline 10 & $\overline{A G}$ & $\overline{A A}$ & $\overline{A G}$ \\
\hline 11 & $\overline{A A}$ & $\overline{G G}$ & $\overline{A A}$ \\
\hline 12 & $\overline{A A}$ & $\overline{G G}$ & $A A$ \\
\hline 13 & $A G$ & $A A$ & $A G$ \\
\hline 14 & GG & $A A$ & $\mathrm{AG}$ \\
\hline 15 & AA & $\mathrm{AG}$ & $A G$ \\
\hline 17 & $A A$ & AA & $\overline{A G}$ \\
\hline 21 & $\overline{A G}$ & GG & $\overline{A G}$ \\
\hline 22 & $\overline{A A}$ & $\overline{G G}$ & GG \\
\hline 23 & $\overline{A A}$ & $\overline{\mathrm{GG}}$ & GG \\
\hline 24 & AG & $A G$ & $A G$ \\
\hline 25 & $\mathrm{AG}$ & $A G$ & AG \\
\hline 26 & $\mathrm{AG}$ & GG & AG \\
\hline 27 & $A G$ & AG & AG \\
\hline 28 & AA & NA & $\overline{A G}$ \\
\hline 29 & AG & $\overline{A G}$ & AG \\
\hline 30 & $\overline{A A}$ & GG & $\overline{A G}$ \\
\hline 31 & $\mathrm{GG}$ & $\overline{A A}$ & $\mathrm{GG}$ \\
\hline 32 & $A A$ & GG & $\mathrm{AG}$ \\
\hline 33 & $\overline{A G}$ & $\overline{A A}$ & $\overline{A G}$ \\
\hline 34 & $A A$ & GG & $\mathrm{AG}$ \\
\hline 35 & $A A$ & GG & $A G$ \\
\hline 36 & $A A$ & GG & $A G$ \\
\hline 37 & NA & GG & $\mathrm{AG}$ \\
\hline 38 & AA & GG & GG \\
\hline 39 & AA & GG & GG \\
\hline 40 & $A A$ & GG & GG \\
\hline 41 & AG & GG & AA \\
\hline 42 & $A A$ & $A A$ & GG \\
\hline 43 & $\overline{A G}$ & GG & $\mathrm{AG}$ \\
\hline 44 & GG & GG & $\overline{A A}$ \\
\hline 45 & GG & $A G$ & $A A$ \\
\hline 46 & $\overline{A G}$ & $\overline{A A}$ & $\overline{A G}$ \\
\hline 47 & $\overline{A A}$ & $\overline{A A}$ & $\overline{A G}$ \\
\hline 48 & AG & $\overline{A G}$ & AG \\
\hline 49 & $\overline{G G}$ & $\overline{A A}$ & $\overline{N A}$ \\
\hline 50 & $\overline{G G}$ & $\overline{A A}$ & GG \\
\hline 51 & $\overline{A A}$ & $\overline{A G}$ & $\overline{A A}$ \\
\hline 52 & $\overline{G G}$ & $A A$ & $A A$ \\
\hline 53 & $\overline{A A}$ & $\overline{A G}$ & NA \\
\hline 54 & $\overline{A G}$ & $\overline{A G}$ & $\overline{A G}$ \\
\hline 55 & $\overline{A G}$ & $\overline{A G}$ & $\overline{A G}$ \\
\hline 56 & $A A$ & AA & NA \\
\hline 57 & $\overline{A A}$ & GG & NA \\
\hline
\end{tabular}

\begin{tabular}{|c|c|}
\hline & LOH \\
\hline & somatic mutation (gain) \\
\hline & No Change \\
\hline & Unknown LOH status \\
\hline & LOH can not be assessed \\
\hline
\end{tabular}

\section{B}

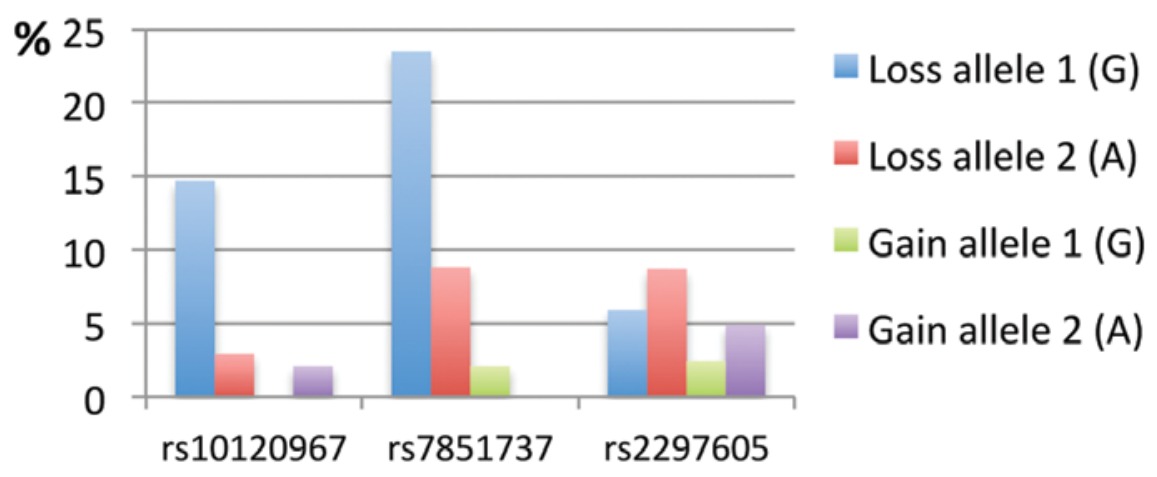

Figure 1. Genotyping reveals somatic NR5A1 gene alterations in ovarian tumors. (A) Genotype distribution by sample. Somatic mutations were identified by genotyping matched ovarian tumors and normal tissue from the same individuals by Taqman SNP genotyping asssays for the indicated SNPs. Only tumor genotypes are shown. (B) Genotyping distribution by SNP. Key: LOH, loss of heterozygosity (e.g. AG>AA); gain, gain of heterozygosity (e.g. GG>AG). Unknown, unclear genotype, for either tumor or normal sample.

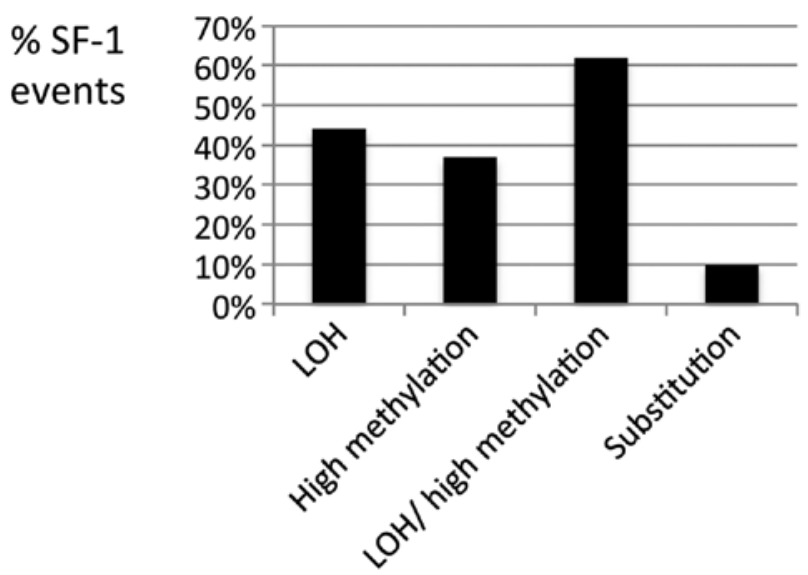

Figure 2. NR5A1 gene alterations in ovarian tumors. Key: High methylation $=3$ rd and 4th quartile of methylation levels (see Materials and methods). Substitution, a somatic mutation other than $\mathrm{LOH}$ (eg. AA>AG). LOH/High methylation, $\mathrm{LOH}$ or high methylation. laser-capture microdissection) and analyzed them following DNA extraction. $\beta$-actin was again amplified from each sample as an internal control. These data show that only one out of the $11(9 \%)$ normal ovaries that were successfully evaluated (i.e. that had $\beta$-actin amplification) showed appreciable NR5Al methylation (Table III). This difference between the prevalence of NR5Al methylation in tumor versus normal ovaries is statistically significant ( $\mathrm{p}<0.0001)$. Thus, ovarian tumor tissues display significantly more frequent $N R 5 A 1$ gene methylation than normal ovarian epithelial tissues.

Clinical correlation. Retrospective analysis of the clinical data suggest that presenting stage and histologic grade of ovarian tumors are not significantly affected by the presence of somatic NR5Al gene alterations (Table I and data not shown). Furthermore, Kaplan-Meier survival curves were similar for both ovarian tumors with and without NR5Al gene alteration (LOH/methylation; data not shown). Likewise, the presence 
Table I. Clinical characteristics of ovarian tumors studied.

\begin{tabular}{|c|c|c|c|c|c|c|c|c|c|}
\hline Age & Race & $\begin{array}{l}\text { Date } \\
\text { of Dx }\end{array}$ & $\begin{array}{l}\text { Study } \\
\text { no. }\end{array}$ & $\begin{array}{c}\text { Years } \\
\text { survived } \\
\text { since Dx }\end{array}$ & Stage & $\begin{array}{l}\text { Histological } \\
\text { grade }\end{array}$ & Surgery & Chemo & Radiation \\
\hline 53 & Black & $6 / 13 / 07$ & $\mathrm{~T} 23$ & Unknown & $3 \mathrm{C}$ & 3 & $6 / 13 / 07$ & Yes & No \\
\hline 62 & White & $6 / 19 / 07$ & $\mathrm{~T} 24$ & $<1$ year & $3 \mathrm{C}$ & 3 & $6 / 19 / 07$ & No & No \\
\hline 32 & White & 4/19/07 & $\mathrm{T} 25$ & $<1$ year & 4 & 3 & $8 / 23 / 07$ & No & No \\
\hline 54 & Black & $12 / 12 / 07$ & T26 & Living & 0 & Borderline & $12 / 12 / 07$ & No & No \\
\hline 31 & White & $1 / 15 / 08$ & $\mathrm{~T} 27$ & Living & 0 & Borderline & $1 / 15 / 08$ & No & No \\
\hline 26 & Black & $2 / 18 / 08$ & T28 & Living & $3 B$ & 1 & $2 / 18 / 08$ & No & No \\
\hline 45 & Hispanic & 4/28/08 & T29 & Living & 0 & 2 & $4 / 29 / 08$ & No & No \\
\hline 64 & White & $5 / 8 / 08$ & T30 & Living & 0 & Borderline & $5 / 18 / 08$ & No & No \\
\hline 60 & White & 8/13/08 & $\mathrm{T} 31$ & Living & $3 \mathrm{C}$ & 3 & $8 / 13 / 08$ & Yes & No \\
\hline 47 & Black & 10/8/08 & T32 & Living & 0 & Borderline & $10 / 8 / 08$ & No & No \\
\hline 55 & White & $10 / 9 / 08$ & T33 & 1 year & $3 \mathrm{C}$ & 2 & $10 / 9 / 08$ & No & No \\
\hline 72 & Unknown & $10 / 27 / 08$ & T34 & Living & $3 \mathrm{C}$ & 3 & $10 / 27 / 08$ & Yes & No \\
\hline 57 & White & 12/7/08 & T35 & $<1$ year & $3 \mathrm{C}$ & Borderline & $12 / 7 / 08$ & Unknown & Unknown \\
\hline 74 & Hispanic & $12 / 11 / 08$ & T36 & Unknown & $3 C$ & 3 & $12 / 11 / 08$ & Yes & No \\
\hline 50 & Black & $1 / 29 / 09$ & T37 & $<1$ year & 4 & 2 & $1 / 29 / 09$ & No & No \\
\hline 49 & Black & $5 / 11 / 09$ & T38 & Living & 0 & Borderline & $5 / 11 / 09$ & No & No \\
\hline 56 & Black & $9 / 28 / 09$ & T39 & Living & $3 \mathrm{~A}$ & 2 & $9 / 28 / 09$ & Yes & Yes \\
\hline 70 & Unknown & 10/1/09 & $\mathrm{T} 40$ & Living & $3 \mathrm{C}$ & 3 & 10/1/09 & Yes & No \\
\hline 46 & Black & $3 / 2 / 07$ & $\mathrm{~T} 21$ & Unknown & $3 \mathrm{C}$ & 3 & $3 / 3 / 07$ & Yes & No \\
\hline 41 & Black & $6 / 12 / 07$ & $\mathrm{~T} 22$ & 1 year & $3 C$ & 3 & $6 / 11 / 07$ & Yes & No \\
\hline 73 & White & $4 / 24 / 97$ & $\mathrm{~T} 10$ & 1 month & $3 \mathrm{~B}$ & 3 & $11 / 24 / 97$ & No & No \\
\hline 41 & Black & 7/21/98 & $\mathrm{T} 8$ & 2 years & 4 & 3 & $7 / 21 / 98$ & Yes & No \\
\hline 69 & White & 4/5/99 & $\mathrm{T} 13$ & 6 years & 4 & 3 & 4/5/99 & Yes & No \\
\hline 63 & Black & $3 / 5 / 00$ & T9 & 2 years & $3 \mathrm{C}$ & 2 & $3 / 5 / 00$ & Yes & No \\
\hline 47 & White & $5 / 31 / 00$ & $\mathrm{~T} 14$ & Living & $3 B$ & 3 & $5 / 31 / 00$ & Yes & No \\
\hline 26 & White & $5 / 21 / 99$ & $\mathrm{~T} 15$ & 3 years & $3 \mathrm{C}$ & 3 & $5 / 21 / 99$ & Yes & Yes \\
\hline 61 & Black & $3 / 5 / 02$ & T49 & $<1$ year & $4 B$ & 2 & $3 / 5 / 02$ & Yes & No \\
\hline 36 & White & $5 / 29 / 02$ & T50 & Living & 0 & Borderline & $5 / 29 / 02$ & No & No \\
\hline 60 & White & $6 / 28 / 02$ & $\mathrm{~T} 11$ & Unknown & $3 \mathrm{C}$ & 2 & $6 / 28 / 02$ & Unknown & Unknown \\
\hline 83 & White & $8 / 9 / 02$ & T51 & $<1$ year & $3 \mathrm{C}$ & 3 & $8 / 9 / 02$ & No & Yes \\
\hline 77 & Hispanic & $3 / 28 / 03$ & T52 & $<1$ year & $4 B$ & 3 & $6 / 13 / 03$ & Yes & No \\
\hline 67 & Black & $9 / 24 / 03$ & T53 & 3 years & $3 \mathrm{C}$ & 3 & $9 / 26 / 03$ & Yes & No \\
\hline 43 & White & $6 / 18 / 01$ & T54 & 2 years & NA & $\begin{array}{l}3^{\text {a }} \text { colon } \\
\text { primary }\end{array}$ & $6 / 18 / 01$ & Yes & No \\
\hline 47 & White & $12 / 19 / 03$ & $\mathrm{~T} 17$ & Living & $3 \mathrm{~A}$ & 3 & $12 / 19 / 03$ & Yes & No \\
\hline 68 & Black & $2 / 16 / 04$ & T55 & $<1$ year & 4 & 3 & $2 / 16 / 04$ & No & No \\
\hline 75 & White & $6 / 20 / 03$ & $\mathrm{~T} 1$ & 2 years & 4 & 3 & $6 / 20 / 03$ & Yes & No \\
\hline 35 & Hispanic & $5 / 25 / 05$ & $\mathrm{~T} 41$ & $<1$ year & $3 \mathrm{C}$ & 2 & $5 / 25 / 05$ & Yes & No \\
\hline 76 & White & 7/20/06 & $\mathrm{T} 42$ & 2 years & $3 \mathrm{C}$ & 3 & $10 / 24 / 06$ & Yes & No \\
\hline 45 & White & $10 / 21 / 02$ & $\mathrm{~T} 12$ & 4 years & $2 \mathrm{~A}$ & & $10 / 21 / 02$ & No & No \\
\hline 60 & NA & $2 / 10 / 02$ & $\mathrm{~T} 4$ & $<1$ year & 4 & 3 & $3 / 5 / 02$ & Yes & No \\
\hline 51 & White & 3/13/07 & $\mathrm{T} 3$ & Living & $3 \mathrm{C}$ & 3 & $3 / 13 / 07$ & Yes & No \\
\hline 70 & Indian & $3 / 16 / 07$ & $\mathrm{~T} 2$ & Unknown & 4 & 3 & $3 / 16 / 07$ & Unknown & Unknown \\
\hline 65 & White & $6 / 8 / 07$ & $\mathrm{~T} 44$ & $<1$ year & 4 & 3 & $6 / 12 / 07$ & No & No \\
\hline 68 & Black & 8/17/07 & $\mathrm{T} 45$ & Living & 4 & $\begin{array}{l}3^{\mathrm{a}} \text { endome- } \\
\text { trial cancer }\end{array}$ & 8/17/07 & No & Yes \\
\hline 64 & White & $6 / 23 / 08$ & T56 & Living & $3 \mathrm{C}$ & 3 & 7/9/08 & Yes & No \\
\hline 49 & White & $6 / 25 / 09$ & $\mathrm{~T} 46$ & Living & $2 \mathrm{~B}$ & Unknown & $6 / 25 / 09$ & No & No \\
\hline 66 & Hispanic & 7/16/09 & $\mathrm{T} 47$ & Living & $3 \mathrm{C}$ & 3 & $7 / 16 / 09$ & Yes & No \\
\hline 51 & White & 8/8/09 & $\mathrm{T} 48$ & Living & $1 \mathrm{~A}$ & 1 & 8/5/09 & No & No \\
\hline 30 & White & $8 / 5 / 09$ & T57 & Living & $1 \mathrm{~A}$ & Borderline & 8/5/09 & No & No \\
\hline
\end{tabular}

Key: Borderline/stage 0 tumors, indicate atypical changes in the ovary that have low malignancy potential. Dx, diagnosis. 
Table II. NR5A1 gene methylation in ovarian tumors.

\begin{tabular}{|c|c|c|}
\hline Samples & Relative intensity & Methylation level \\
\hline $\mathrm{T} 1$ & 0.24 & - \\
\hline $\mathrm{T} 2$ & 0.81 & ++ \\
\hline T3 & 1.14 & +++ \\
\hline $\mathrm{T} 4$ & 0.78 & ++ \\
\hline T8 & 0.35 & + \\
\hline T9 & 0.72 & ++ \\
\hline $\mathrm{T} 10$ & 0.02 & - \\
\hline $\mathrm{T} 11$ & 0.34 & + \\
\hline $\mathrm{T} 12$ & 0.40 & + \\
\hline T13 & 0.77 & ++ \\
\hline T14 & 0.48 & + \\
\hline $\mathrm{T} 15$ & 0.54 & + \\
\hline $\mathrm{T} 17$ & 0.40 & + \\
\hline $\mathrm{T} 21$ & 0.45 & + \\
\hline $\mathrm{T} 22$ & 0.62 & ++ \\
\hline $\mathrm{T} 23$ & 0.58 & ++ \\
\hline $\mathrm{T} 24$ & 0.56 & + \\
\hline $\mathrm{T} 25$ & 0.68 & ++ \\
\hline $\mathrm{T} 26$ & 0.37 & + \\
\hline $\mathrm{T} 27$ & 0.87 & +++ \\
\hline T28 & 0.55 & + \\
\hline $\mathrm{T} 29$ & 0.78 & ++ \\
\hline $\mathrm{T} 30$ & 0.83 & ++ \\
\hline $\mathrm{T} 31$ & 0.58 & ++ \\
\hline T32 & 0.09 & - \\
\hline T33 & 0.57 & + \\
\hline T34 & 0.32 & + \\
\hline T35 & 0.17 & - \\
\hline T36 & 0.53 & + \\
\hline $\mathrm{T} 37$ & 0.43 & + \\
\hline T38 & 0.54 & + \\
\hline T39 & 0.57 & ++ \\
\hline $\mathrm{T} 40$ & 0.42 & + \\
\hline $\mathrm{T} 41$ & NA & NA \\
\hline $\mathrm{T} 42$ & 0.75 & ++ \\
\hline $\mathrm{T} 43$ & NA & NA \\
\hline T44 & 0.14 & - \\
\hline $\mathrm{T} 45$ & 0.00 & - \\
\hline T46 & 1.14 & +++ \\
\hline $\mathrm{T} 47$ & NA & NA \\
\hline T48 & NA & NA \\
\hline T49 & 0.10 & - \\
\hline T50 & 0.11 & - \\
\hline T51 & 0.79 & ++ \\
\hline T52 & 0.53 & + \\
\hline T53 & 1.07 & +++ \\
\hline T54 & 0.00 & - \\
\hline T55 & 0.00 & - \\
\hline T56 & 0.54 & + \\
\hline T57 & 0.30 & + \\
\hline
\end{tabular}

Methylation was quantified by the methylation-sensitive restriction enzyme method. Relative intensity, NR5A1/ $\beta$-actin band intensity. Methylation level is indicated by quartiles of relative intensity: -, 1st; ,+ 2 nd;,++ 3 rd; and +++, 4th quartile.
Table III. NR5A1 gene methylation in normal ovaries.

\begin{tabular}{lcc}
\hline Samples & Relative intensity & Methylation level \\
\hline N41 & 0 & - \\
N61 & 1.5 & +++ \\
N44 & 0.1 & - \\
N34 & NA & NA \\
N45 & 0.16 & - \\
N60 & 0 & - \\
N42 & 0 & - \\
N59 & 0 & - \\
N52 & 0 & - \\
N29 & NA & NA \\
N51 & 0 & - \\
N38 & 0 & - \\
N54 & NA & NA \\
N53 & 0.21 & - \\
N57 & NA & NA \\
N27 & NA & NA \\
\hline
\end{tabular}

Bold indicates samples with available tumor. The numbers for normal (N) tissue are scrambled, and do not correspond to the tumor (T) tissue numbers. For key, see Table II.

of NR5Al gene alteration did not correlate with race/ethnicity or treatment, such as radiation and chemotherapy (Table I and data not shown).

\section{Discussion}

A common feature of many tumor suppressor genes is their inactivation in cancer tissue through $\mathrm{LOH}$ and other somatic mutations. In ovarian tumors, $\mathrm{LOH}$ and somatic mutations have been documented for tumor suppressors such as TP53, BRCA1, BRCA2 and PTEN (21). The data presented herein support such a role for human SF-1, and may provide a molecular mechanism to partially explain the loss of SF-1 protein reported in both ovarian tumors and ovarian cancer cell lines. Specifically, the data demonstrate that most ovarian tumors contain genetic and/or epigenetic alterations at the NR5Al locus, significantly more frequently compared to normal ovaries. These somatic alterations include $\mathrm{LOH}$, base substitution, and methylation of the NR5Al gene promoter. The absence of correlation between the presence of somatic NR5Al gene alteration and disease treatment (radiation/ chemotherapy) suggests that these somatic events are not the result of cancer treatment. These data suggest the need for scanning the NR5Al gene for somatic mutations in larger datasets, with diverse racial/ethnic groups, and perhaps in other types of tumor tissues controlled by SF-1.

Given the prevalence of somatic events at the NR5Al locus, we attempted to examine the contribution of these molecular events on clinical endpoints, such as disease progression and survival. Interestingly, genetic and epigenetic NR5A1 alterations do not correlate with markers of tumor progression (grade/stage) or survival. This finding suggests that somatic NR5Al alterations may be early events in ovarian 
carcinogenesis. Analysis of the early stage/grade tumors in our dataset suggests a similar prevalence of somatic NR5AI alterations in advanced and non-advanced tumors (data not shown). However, this interpretation is tempered by the existence of low numbers of non-advanced tumors in our dataset (Table I). Examination of larger numbers of non-advanced and/or benign tumors for somatic NR5Al alterations, may help confirming this concept.

The finding of somatic NR5Al gene mutations (gain of allele substitutions) in $10 \%$ of the ovarian tumors (Fig. 2) is striking, given the fact that we interrogated only three base pairs of the NR5Al gene in these assays (the three SNP positions). This fact together with the finding of $\mathrm{LOH}$ at this locus in $44 \%$ of the ovarian tumors (Fig. 2), strongly suggest a high somatic mutation frequency of the NR5Al gene in ovarian cancer. Thus, the $N R 5 A 1$ gene should be screened for somatic mutations by a more comprehensive method (such as sequencing) in both advanced and benign ovarian tumors, especially tumors that show $\mathrm{LOH}$. This analysis should include the NR5Al gene promoter, since SF-1 protein expression is lost in both human ovarian tumors and tumor cell lines. Identification of a somatic mutation and/ or methylation together with $\mathrm{LOH}$ in the same tumor, may explain the loss of SF-1 protein reported in ovarian tumor tissue. To that effect, the detection of both a high level of NR5Al gene methylation and $\mathrm{LOH}$ in $21 \%$ of the ovarian tumors that we analyzed (Fig. 1 and Table II), may partially explain this loss.

LOH can be caused by two different mechanisms in tumor cells: i) deletion (loss of allele/gene) or ii) base substitution (which includes gene conversion). Although $14 \%$ of the tumors had multiple LOH events (Fig. 1) suggesting a deletion at the NR5A1 locus, the majority of LOH events involved only one (out of three possible) SNPs at the NR5A1 locus (Fig. 1), suggesting no extensive $N R 5 A 1$ deletion, at least around the three interrogated SNPs. However, even a microdeletion involving only the genomic area around a single NR5A1 SNP can affect SF-1 protein expression. Also, gene conversion involves recombination (22), which may cause deletions, rearrangements and other functionally important (for SF-1 expression) genetic events upstream or downstream from the interrogated SNPs (undetected by our assay). Furthermore, both molecular heterogeneity within the same tumor and contamination with normal cells can result in underestimation of the extent of $\mathrm{LOH}$, or confinement of the observed $\mathrm{LOH}$ in a smaller genetic region. In addition, the high somatic mutation frequency observed at the NR5AI locus may have functional effects. Therefore, the frequently observed genetic ( $\mathrm{LOH} /$ substitution) events at the NR5Al locus may significantly contribute to the reported loss of SF-1 protein in ovarian tumor tissue.

A limitation of the methylation-sensitive restriction enzyme method utilized here is that the use of PCR, which exponentially amplifies the target DNA, makes the method less quantitative. For this reason, we included $\beta$-actin as an internal control, and also focused our methylation analysis on quartiles of methylation rather than absolute levels. The significant difference observed in the frequency of appreciable methylation (2nd quartile or higher) between tumor and normal ovarian tissue (Tables II and III) suggests that NR5AI methylation is much more prevalent in tumors. The exact degree of methylation, and the subsequent reduction of SF-1 protein, is hard to estimate from these data. However, the fact that the $37 \%$ of the ovarian tumors that show high methylation (++ or higher methylation level; Fig. 2) display $>57 \%$ of the band intensity of $\beta$-actin (Table II), suggests that a significant proportion of the NR5A1 gene is methylated in these ovarian tumors in vivo. Thus methylation may be a major molecular mechanism leading to the reported loss of SF-1 protein in ovarian tumors.

Interestingly, hypomethylation and subsequent transcriptional activation of SF-1 has been reported in endometriosis, an estrogen dependent disease (23). In contrast, hypermethylation leading to silencing of gene expression has been reported in ovarian tumors for multiple key tumor suppressor genes including BRCA1, BRCA2, WT1, APC, CDKN2A and MLH1 (24,25).

In conclusion, we report frequent somatic alterations of the NR5A1 locus in ovarian tumors, including LOH, base substitution, and methylation of the NR5A1 gene promoter. These molecular abnormalities may partially explain the loss of SF-1 protein, and contribute to the model of SF-1 as an ovarian tumor suppressor. The existence of both genetic and epigenetic NR5A1 gene abnormalities in ovarian tumors further suggest that SF-1 is a common and important target in ovarian carcinogenesis.

\section{Acknowledgements}

NMM is supported by grants P20GM103518, from the National Institutes of Health and PC094628, from the Department of Defense.

\section{References}

1. Ozols RF: Treatment goals in ovarian cancer. Int J Gynecol Cancer 15 (Suppl 1): 3-11, 2005.

2. Leung PC and Choi JH: Endocrine signaling in ovarian surface epithelium and cancer. Hum Reprod Update 13: 143-162, 2007.

3. Rae MT, Niven D, Ross A, Forster T, Lathe R, Critchley HOD, Ghazal $\mathrm{P}$ and Hillier SG: Steroid signalling in human ovarian surface epithelial cells: the response to interleukin-1alpha determined by microarray analysis. J Endocrinol 183: 19-28, 2004.

4. Papacleovoulou G, Hogg K, Fegan KS, Critchley HO, Hillier SG and Mason JI: Regulation of 3beta-hydroxysteroid dehydrogenase type 1 and type 2 gene expression and function in the human ovarian surface epithelium by cytokines. Mol Hum Reprod 15: 379-392, 2009.

5. Ivarsson K, Sundfeldt K, Brannstrom $M$ and Janson PO: Production of steroids by human ovarian surface epithelial cells in culture: possible role of progesterone as growth inhibitor. Gynecol Oncol 82: 116-121, 2001.

6. Okamura $\mathrm{H}$, Katabuchi $\mathrm{H}$ and Ohba T: What we have learned from isolated cells from human ovary? Mol Cell Endocrinol 202: 37-45, 2003.

7. Nash DM, Hess SA, White BA and Peluso JJ: Steroidogenic factor-1 regulates the rate of proliferation of normal and neoplastic rat ovarian surface epithelial cells in vitro. Endocrinology 139: 4663-4671, 1998.

8. Batsche E, Desroches J, Bilodeau S, Gauthier Y and Drouin J: $\mathrm{Rb}$ enhances p160/SRC coactivator-dependent activity of nuclear receptors and hormone responsiveness. J Biol Chem 280: 19746-19756, 2005.

9. Tran PV, Akana SF, Malkovska I, Dallman MF, Parada LF and Ingraham HA: Diminished hypothalamic bdnf expression and impaired VMH function are associated with reduced SF-1 gene dosage. J Comp Neurol 498: 637-648, 2006.

10. Syed V, Ulinski G, Mok SC, Yiu GK and Ho SM: Expression of gonadotropin receptor and growth responses to key reproductive hormones in normal and malignant human ovarian surface epithelial cells. Cancer Res 61: 6768-6776, 2001.

11. Hinkula M, Pukkala E, Kyyrönen P and Kauppila A: Incidence of ovarian cancer of grand multiparous women - A population-based study in Finland. Gynecol Oncol 103: 207-211, 2006. 
12. Sugawara T, Kiriakidou M, McAllister JM, Holt JA, Arakane F and Strauss JF III: Regulation of expression of the steroidogenic acute regulatory protein (StAR) gene: a central role for steroidogenic factor 1 . Steroids 62: 5-9, 1997.

13. Fujieda K, Tajima T, Nakae J, Sageshima S, Tachibana K, Suwa S, Sugawara T and Strauss JF III: Spontaneous puberty in $46, \mathrm{XX}$ subjects with congenital lipoid adrenal hyperplasia. Ovarian steroidogenesis is spared to some extent despite inactivating mutations in the steroidogenic acute regulatory protein (StAR) gene. J Clin Invest 99: 1265-1271, 1997.

14. Ramayya MS, Sheng M, Moroz K, Hill SM and Rowan BG: Human steroidogenic factor-1 (hSF-1) regulates progesterone biosynthesis and growth of ovarian surface epithelial cancer cells. J Steroid Biochem Mol Biol 119: 14-25, 2010.

15. Abd-Elaziz M, Moriya T, Akahira J, Suzuki T and Sasano H: StAR and progesterone producing enzymes (3beta-hydroxysteroid dehydrogenase and cholesterol side-chain cleavage cytochromes P450) in human epithelial ovarian carcinoma: immunohistochemical and real-time PCR studies. Cancer Sci 96: 232-239, 2005

16. Taketo M, Parker KL, Howard TA, Tsukiyama T, Wong M, Niwa O, Morton CC, Miron PM and Seldin MF: Homologs of Drosophila Fushi-Tarazu factor 1 map to mouse chromosome 2 and human chromosome 9q33. Genomics 25: 565-567, 1995.

17. Schultz DC, Vanderveer L, Buetow KH, Boente MP, Ozols RF, Hamilton TC and Godwin AK: Characterization of chromosome 9 in human ovarian neoplasia identifies frequent genetic imbalance on $9 \mathrm{q}$ and rare alterations involving $9 \mathrm{p}$, including CDKN2. Cancer Res 55: 2150-2157, 1995.

18. HoivikEA, AumoL, Aesoy R,Lillefosse H,Lewis AE, Perrett RM, Stallings NR, Hanley NA and Bakke M: Deoxyribonucleic acid methylation controls cell type-specific expression of steroidogenic factor 1. Endocrinology 149: 5599-5609, 2008.
19. Nakamura J, Kitajima Y, Kai K, Hashiguchi K, Hiraki M, Noshiro $\mathrm{H}$ and Miyazaki K: Expression of hypoxic marker CA IX is regulated by site-specific DNA methylation and is associated with the histology of gastric cancer. Am J Pathol 178: 515-524, 2011.

20. Seidman JD, Russell P and Kurman RJ: Surface epithelial tumors of the ovary. In: Blausten's pathology of the female genital tract. Kurman RJ (ed). 5th ed. Springer, New York, pp791-904, 2002.

21. Despierre E, Lambrechts D, Neven P, Amant F, Lambrechts S and Vergote I: The molecular genetic basis of ovarian cancer and its roadmap towards a better treatment. Gynecol Oncol 117: 358-365, 2010.

22. Chen JM, Cooper DN, Chuzhanova N, Férec C and Patrinos GP: Gene conversion: mechanisms, evolution and human disease. Nat Rev Genet 8: 762-775, 2007.

23. Xue Q, Lin Z, Yin P, Milad MP, Cheng YH, Confino E, Reierstad S and Bulun SE: Transcriptional activation of steroidogenic factor-1 by hypomethylation of the $5^{\prime} \mathrm{CpG}$ island in endometriosis. J Clin Endocrinol Metab 92: 3261-3267, 2007.

24. Balch C, Fang F, Matei DE, Huang TH and Nephew KP: Minireview: epigenetic changes in ovarian cancer. Endocrinology 150: 4003-4011, 2009.

25. Barton CA, Hacker NF, Clark SJ and O'Brien PM: DNA methylation changes in ovarian cancer: implications for early diagnosis, prognosis and treatment. Gynecol Oncol 109: $129-139,2008$ 